NBER WORKING PAPER SERIES

ANTEBELLUM TARIFF POLITICS:
COALITION FORMATION
AND SHIFTING REGIONAL INTERESTS

Douglas A. Irwin

Working Paper 12161

http://www.nber.org/papers/w12161

\author{
NATIONAL BUREAU OF ECONOMIC RESEARCH \\ 1050 Massachusetts Avenue \\ Cambridge, MA 02138 \\ April 2006
}

I thank John Majewski, Robert McGuire, and seminar participants at Dartmouth, Cornell, and Tulane for helpful comments on earlier versions of this paper. William Congdon provided excellent research assistance. The financial support of the National Science Foundation is gratefully acknowledged. The views expressed herein are those of the author(s) and do not necessarily reflect the views of the National Bureau of Economic Research.

(C2006 by Douglas A. Irwin. All rights reserved. Short sections of text, not to exceed two paragraphs, may be quoted without explicit permission provided that full credit, including $\odot$ notice, is given to the source. 
Antebellum Tariff Politics: Coalition Formation and Shifting Regional Interests

Douglas A. Irwin

NBER Working Paper No. 12161

April 2006

JEL No. F1, N7

\begin{abstract}
Throughout U.S. history, import tariffs have been put on a sustained downward path in only two instances: from the early-1830s until the Civil War and from the mid-1930s to the present. This paper analyzes how the movement toward higher tariffs in the 1820s was reversed for the rest of the antebellum period. Tariff politics in Congress during this period was highly sectional: the North supported high tariffs, the South favored low tariffs, and the West was a "swing" region. In the 1820s, a coalition between the North and West raised tariffs by exchanging votes on import duties for spending on internal improvements. President Andrew Jackson effectively delinked these issues and destroyed the North-West alliance by vetoing several internal improvements bills. South Carolina's refusal to enforce the existing high tariffs sparked the nullification crisis and paved the way for the Compromise Tariff of 1833, which promised to phase out tariffs above 20 percent over a nine year period. Although Congress could not credibly commit itself to the staged reductions or maintaining the lower duties, the growing export interests of the West - due, ironically, to transportation improvements that made agricultural shipments economically viable - gave the region a stake with the South in maintaining a low tariff equilibrium. Thus, the West's changing position on trade policy helps explain the rise and fall of tariffs over this period.
\end{abstract}

Douglas A. Irwin

Department of Economics

Dartmouth College

Hanover, NH 03755

and NBER

douglas.irwin@dartmouth.edu 


\title{
Antebellum Tariff Politics: Coalition Formation and Shifting Regional Interests
}

\author{
"Destroy the tariff and you will leave no means of carrying \\ on internal improvements; destroy internal improvements \\ and you leave no motive for the tariff." - Senator William \\ Smith (D - SC)
}

\section{Introduction}

Economists studying the political economy of trade policy usually focus on the pressures for greater protectionism, but the forces behind successful efforts at trade liberalization deserve equal consideration. In the history of the United States, for example, import tariffs been put on a sustained downward path in just two instances: from the mid-1830s until the Civil War, and from the mid-1930s to the present. The decline in tariffs since the mid-1930s was facilitated by a major change in the institutional structure of trade-policy making, namely, the Reciprocal Trade Agreements Act of 1934, in which Congress delegated trade negotiating powers to the president. The combination of changes in the structure of policymaking and shifts in underlying traderelated economic interests as a result of World War II helped ensure that the initial move toward lower tariffs was sustained over time. ${ }^{1}$

The only other episode of sustained reduction in U.S. tariffs occurred in the quarter century prior to the Civil War. As Figure 1 shows, the average U.S. tariff on dutiable imports rose steadily through the 1820 s and reached more than 60 percent by the end of the decade, their highest level in U.S. history, even higher than under the Hawley-Smoot tariff of 1930.

Manufacturing industries in the North succeeded in pressing for high protective tariffs against the implacable opposition of the South, where the export-dependent crops of cotton and tobacco

1 See the analyses of Bailey, Goldstein, and Weingast (1997) and Irwin and Kroszner 
were produced. In 1832, South Carolina sparked a major crisis by refusing to enforce the tariff law, claiming the right to "nullify" any objectionable Federal legislation and even threatening to secede from the Union. The Compromise Tariff of 1833 defused the crisis and set out a timetable for staged reductions in import duties that put tariffs on a downward path until 1860.

Tariffs were never a more divisive or sectional issue in American politics than during the antebellum period, and yet the political dynamics that led to their rise and fall over this period are not well understood. ${ }^{2}$ Unlike the 1930 s, the institutional method of formulating tariff policy did not change as Congress retained full control over the setting of tariff rates. Nor did the traderelated economic interests of the various regions of the country appear to shift in any pronounced way: throughout the period, the South produced and exported cotton and tobacco, the North was home to import-competing manufacturing industries, and the West specialized in producing wheat, flour, and other agricultural goods. So why did tariffs rise during the 1820 s only to fall in the decades after 1833 ?

This paper examines the political and economic factors behind U.S. trade policy during this period by focusing on three key questions: (i) what coalition in Congress was responsible for raising import tariffs during the 1820s? (ii) why did this coalition break down, setting the stage for the Compromise of 1833 ? (iii) how was the compromise's promise of staged tariff reductions over time sustained when intertemporal legislative bargains are impossible to enforce?

The answers to these questions can be briefly anticipated as follows. Before the

2 Pincus's (1977) study of the political and economic determinants of tariff rates by industry in 1824 finds that more concentrated industries obtained greater protection. However, he does not examine the evolution of Congressional voting patterns through this period and therefore does not explain why these tariffs were reversed just five years later. 
Compromise of 1833, tariff policy was closely linked to the issue of internal improvements. As the epigram to this paper suggests, import duties raised the revenue that could be spent on such improvements, and the desire to have such improvements justified having high tariffs. In the 1820s, members of Congress from the North and the West formed a logrolling coalition that traded votes on high tariffs and internal improvement spending, the so-called American System championed by Henry Clay. President Andrew Jackson's veto of internal improvement bills in 1830 broke the link between the two issues and effectively destroyed this coalition. At the same time, South Carolina dramatically raised the stakes by attempting to "nullify" the existing tariffs, creating the necessity for a compromise measure in 1833 that planned to phase out protectionist tariffs over nine years and then keep the tariffs low.

Although Congress could not commit future legislators to adhere to the terms of the compromise, the political bargain held for most of the pre-Civil War period. The reason it held is that the West's farm-based constituents were increasingly tied to export markets, due to reductions in transportation costs from railroads. As a result, their Congressional representatives began supporting low tariffs along with the South. Thus, the shifting support of the West helps explain the political dynamics that account for the rise and fall of tariffs over the antebellum period.

\section{Coalitions in Antebellum Tariff Politics}

The antebellum period stands out as one in which sectional interests dominated national politics. At the risk of oversimplification, the United States during this period consisted of three regions - the North, the South, and the West. Each region had strikingly different preferences 
over tariff policy, which was one of the most controversial political issue of the day, perhaps second only to slavery.

These policy preferences are fairly straightforward to describe: in general, the North favored high protectionist tariffs, the South favored low revenue tariffs, and the West - at least initially - had less clearly defined interests regarding trade policy. The high concentration of trade-related economic interests in the North and South largely accounts for their preferences. The North was the location of nascent manufacturing industries, such as the cotton textile factories of Massachusetts and the iron works of Pennsylvania. These industries faced import competition from British producers, and thus members of Congress from the region tended to support high tariffs. In the 1820 s, however, such support was not always uniform. While representatives from the mid-Atlantic states, particularly Pennsylvania and New Jersey, were strong supporters of protective tariffs, those from New England and New York were more mixed. New England shipping interests and New York mercantile interests gave constituents in those areas a stake in open and flourishing trade, not high tariffs. However, at least in New England, the strength of these pro-trade interests gradually lost ground to the more protectionist interests of cotton and woollen manufacturers, who feared foreign competition. The shift in position of Senator Daniel Webster of Massachusetts, who opposed commercial restrictions in the early 1820 s but came to defend high tariffs by the end of the decade, best illustrates the flexibility of politicians in adjusting to the changing interests of their constituents.

The South produced the leading exports of the United States. Cotton, tobacco, and rice accounted for about two-thirds of U.S. exports in 1830 and these crops were produced almost exclusively in states such as North and South Carolina and Virginia. A large share of domestic 
production was exported; in the case of cotton, about three quarters of the crop was sent to foreign markets. Thus, the major economic interests in the South had a strong export-orientation and hence Southern politicians, representing their plantation-owner constituents, passionately opposed high tariffs. As with the North, there were some exceptions to this rule: legislators from Louisiana often voted in favor of high tariffs to ensure that duties on imported sugar would protect those farmers in their state. But most Southern politicians denounced tariffs as a sectional tax that hit the region twice, first as an indirect tax on their exports and then as a direct tax on the manufactured goods they consumed. These politicians advocated a low, uniform tariff on imports designed only to raise revenue, not to protect domestic industries, and limits on government spending to minimize the need for tariff revenue.

The West (the Midwest of today) specialized in the production of agricultural crops, such as wheat and corn, and animal products. While the import-competing and export-oriented economic interests of the North and the South were fairly evident, the trade-related economic interests of the West - at least initially - were not as sharply defined because high transportation costs kept the region relatively isolated from international trade. The Northwest, including Ohio and Illinois, specialized in agricultural crops and animal products, goods that the United States exported to some degree. Indeed, flour was the second largest U.S. export after cotton, amounting to over 10 percent of total exports in 1830, and other foodstuffs (such as pork, lard, and grains) were exported as well. Yet such exports comprised only a small share of the total domestic production of these goods. The Southwest, including Kentucky and Tennessee, produced hemp that faced competition from imports to a slight degree. As a result, the West did 
not have as strong an economic stake in trade as the other regions. ${ }^{3}$

Because of its limited interest in trade, the West was a potential swing vote in Congress on the tariff issue. Indeed, the West was the "pivotal player in the political system" due to its position between the opposing interests of the North and South on many issues, notably slavery, and because neither the North or the South commanded an absolute majority in the Congress (Weingast 1998, p. 160). As Table 1 shows, in 1820 the North held 54 percent of seats in the House of Representatives, although this was often divided between opposing political parties, and accounted for less than fifty percent of the Senate. Both the North and the South needed support from the West to enact its legislative agenda. And the West grew in political strength over the course of the antebellum period, largely at the expense of the North. By 1850, the West controlled more than a quarter of the seats in Congress.

Table 2 presents House and Senate votes on major antebellum tariff legislation and documents how the swing votes of the West were critical to the passage of tariff legislation in the 1820s. In the 1824 and 1828 tariff legislation, each of which pushed tariffs higher, the votes in the House and Senate were virtually identical: about two-thirds of Senators from the North supported the measure, while the South was nearly unanimously opposed. In both cases, the South would have been able to block the higher tariffs had it not been for the votes of the West. Representatives from the West supported higher tariffs and this support was crucial to the passage of the legislation in both chambers.

3 As we shall see, however, the spread of railroads in the 1840s and 1850s allowed agricultural products (principally wheat and flour) from northwestern states to reach the east coast and foreign markets, giving the region a much greater export-orientation than it previously had. 
How were the pro-tariff forces in the North able to persuade representatives from the West to vote for tariff measures that were not obviously in their economic interest? The apparent answer is that the West had something to gain on an issue of even greater important to them internal improvements. The West strongly supported federal spending on canals, roads, and other transportation improvements as a way of reducing its economic isolation (Larson 2001). Support for internal improvements in the North was mixed. Representatives from the midAtlantic region endorsed such expenditures because the region's geographic position made it the logical place for outlets from states west of the Appalachian mountains. The mid-Atlantic therefore stood to gain a disproportionate share of federal spending. Representatives from New York (after the construction of the Erie Canal) and New England (geographically separated from the West) were more tepid in their support. But, in general, the North was willing to spend the revenues generated by high tariffs on internal improvement projects which were of great value to the West.

Senator Henry Clay of Kentucky was the politician most responsible for creating this coalition by championing what he called the "American System." The American System was an effort to bind the various regions of the country together into a single interdependent entity by a policy of internal improvements and encouragement of manufactures. Supporters of the system believed that the various interests of the country could be brought together in harmony because agriculture and industry were reciprocally dependent upon one another. The growth of manufacturing industries under the tariff in the North created the demand for agricultural goods from the West, which could then exchange its products for the implements and clothing produced in the North. Therefore, in Clay's scheme, the West should be willing to support the tariffs that 
benefitted the North in exchange for Northern support for internal improvements. ${ }^{4}$ In addition, high tariffs would raise the revenue needed to finance such internal improvements.

The tariff debates in Congress made many veiled and not-so-veiled references to the coalition behind the American System. Writing to Daniel Webster in 1827, Clay noted that he was "most anxious . . that they [internal improvements] should be supported in New England, and that the West and Pennsa. should be made sensible of that support. . . You have your equivalents in other forms. ... We must keep the two interests of D[omestic] M[anufactures] \& I[nternal] I[mprovements] allied" (Feller 1984, p. 91). ${ }^{5}$ Daniel Webster needled representatives from North Carolina, who generally opposed tariffs but had voted for a duty on molasses, by reminding them what the tariffs were for: "so long as they choose to compel their constituents, and my constituents, to pay a molasses tax, the proceeds thereof shall be appropriated, as far as I am concerned, to valuable national objects, in useful and necessary works of Internal

${ }^{4}$ As Sellers (1991, p. 290) put it, “The logrolling genius of Clay’s American System linked protectionism with internal improvements. Northwestern entrepreneurs backed high tariffs to provide revenue for roads and canals, while northeastern manufacturers supported transportation appropriations to sop up surplus revenues that might force tariff reductions. The Ohio valley states opened the constitutional floodgate in 1824 by voting unanimously for the General Survey Act as well as for the tariff. Promptly Carolina's quondam nationalists turned against internal improvements, but the loss was more than made up for by increasing support from New England."

${ }^{5}$ Not all historians have thought such a bargain necessary. According to Feller (1984, p. 120), "The American System coalition is often accounted [as] a simple tradeoff between Western internal improvement men and Northeastern manufacturers. But for the original parties to the axis, the Northwest and the mid-Atlantic states, no such bargain was necessary. Each supported the system for its own reasons. The mid-Atlantic states (except New York after completing the Erie Canal) wanted federal aid for internal improvements, and Northwesterners favored a protective tariff." But as we shall see, Northwesterners did not support protective tariffs for long. 
Improvements" (May 9, 1828, p. 757). ${ }^{6}$

The great failure of American System advocates was their inability to produce and enact a comprehensive plan for either internal improvements or the encouragement of manufactures (Larson 2001, Minicucci 2004). In 1824, Congress passed the General Survey Act which authorized the preparation of detailed plans for national internal improvement projects. Despite the support of President John Quincy Adams, no systematic program emerged from the surveys. Rather, internal improvements proceeded in a piecemeal fashion, in which politicians got to pick and choose which canal or road projects to support. The result was an ad hoc political process whereby Congress set about "advancing pet projects with increasingly dubious claims of national significance and indulging in ever more bitter attacks on each other" (Larson 2001, pp. 165-66).

Meanwhile, the South bitterly opposed both high tariffs and spending on internal improvements. The South did not see how it stood to gain from the American System. High tariffs were directly counter to its economic interests because it exported most of its produce, and the South was not geographically positioned to benefit from federal spending on internal improvements. As Table 3 shows, the geographic distribution of federal spending on internal improvements was highly skewed toward the West. During the 1820s, the North and West received more than two-thirds of all federal spending, while the South took in less than 20 percent. The South was not the best location for canals running from the west to the east and it already had the Mississippi River and New Orleans as outlets for Western crops. Furthermore, spending on internal improvements was a justification for keeping tariff rates high. In the view

${ }^{6}$ Unless otherwise noted, all quotes from members of Congress are taken from the $\underline{\text { Register of Debates in Congress }}$ or Congressional Globe, citing the date and page number. 
of the South, the tariff was not just an indirect tax on its exports and a direct tax on the manufactured goods that it consumed, but the revenues generated by the duties were spent in other regions of the country. Southern politicians assailed the tariff for siphoning off resources from the South, leading to impassioned cries that it was being oppressed and exploited by the other regions of the country.

Empirical evidence of a link between votes on tariffs and internal improvements can be shown more formally using Stratmann's (1992) method for detecting log-rolling coalitions in Congressional votes. The vote of each Senator can be expressed as a function of the Senator's overall voting pattern (ideology) and state-level economic characteristics:

$$
\mathrm{V}_{\mathrm{T}}=\mathrm{a}_{1}+\mathrm{b}_{1} \mathrm{X}_{\mathrm{C}}+\mathrm{c}_{1} \mathrm{X}_{\mathrm{E}}+\mu_{1}
$$

where $\mathrm{V}_{\mathrm{T}}$ is a binary variable $(0,1)$ indicating a Senator's votes on a tariff bill, $\mathrm{X}_{\mathrm{C}}$ is a vector of the political characteristics of the member of Congress, $\mathrm{X}_{\mathrm{E}}$ is a vector of the economic interests in the Congressman's state, and $\mu$ is the error term. As Stratmann (1992) notes, however, if there is a logrolling coalition between supporters of tariffs and internal improvements, however, equation (1) will be incomplete. Instead, it should be specified as:

$$
\mathrm{V}_{\mathrm{T}}=\mathrm{a}_{2}+\mathrm{d}_{2} \mathrm{v}_{\mathrm{I}}+\mathrm{b}_{2} \mathrm{X}_{\mathrm{C}}+\mathrm{c}_{2} \mathrm{X}_{\mathrm{E}}+\mu_{2}
$$

where $\mathrm{v}_{\mathrm{I}}$ is the Senator's predicted vote on internal improvements. The analogous equation for votes on internal improvements being

$$
\mathrm{V}_{\mathrm{I}}=\mathrm{a}_{3}+\mathrm{b}_{3} \mathrm{X}_{\mathrm{C}}+\mathrm{c}_{3} \mathrm{X}_{\mathrm{E}}+\mu_{3}
$$

and the predicted value from this equation is $\mathrm{V}_{\mathrm{I}}$. Similarly, the correct specification for the internal improvement vote is

$$
\mathrm{V}_{\mathrm{I}}=\mathrm{a}_{4}+\mathrm{d}_{4} \mathrm{v}_{\mathrm{T}}+\mathrm{b}_{4} \mathrm{X}_{\mathrm{C}}+\mathrm{c}_{4} \mathrm{X}_{\mathrm{E}}+\mu_{4}
$$


where $v_{T}$ is the predicted vote from equation (1). The test for logrolling is that $d_{2}>0$ and $d_{4}>0$. These coefficients will be identified because the economic interests at stake will not be the same in each equation.

Using this framework, Table 4 presents the empirical results from the Senate vote on the Tariff of 1828 held on May 13, 1828. In column 1, the sole explanatory variable is the Poole and Rosenthal (1997) first-dimensional "ideology" score. This single variable correctly predicts 68 percent of the Senate votes. Column 2 includes just state-level economic interest variables taken from the Census of 1840 (the closest one to the 1828 vote, as the 1830 Census did not present economic data; Statistics of the United States of America, $6^{\text {th }}$ Census, June 1, 1840, Washington, D.C.: Blair and Rives, 1841, pp. 408-409). Although these variables are for the year 1840, the geographic pattern of production across states had not changed significantly since 1828 . These variables include per capita production of export-related goods (raw cotton, tobacco, ships, and wheat) and import-competing products (wool, iron, and hemp manufactures and sugar). Most of the export-oriented production is located in the South, with the exception of the ship-building industry (in New England) and wheat production (West). Most of the import-competing industries are located in the North (production of woolens takes place in essentially the same locations as cotton textiles), with the exception of hemp (West) and sugar (Louisiana).

The results in column 2 indicate that the economic interest variables explain more of the variation in the Senate vote than the ideology score alone. Most of the variables take the anticipated sign; that is, a Senator from a state with a high concentration of cotton and tobacco production are likely to have voted against the tariff (both explanatory variables are statistically significant), whereas Senators from states with a heavy concentration of sugar, iron, and hemp 
production were likely to vote in favor of the tariff. Note that Senators from states with a concentration of wheat production are more likely to vote in favor of the tariff, although this is not statistically significant. Column 3 combines a Senator's ideology with the economic interest variables. This equation explains over ninety percent of the variance in the vote pattern and correctly predicts over ninety percent of the votes.

If the tariff issue was linked to internal improvement, then a predicted vote on internal improvements might add explanatory power to the tariff vote regression. Just two weeks prior to the vote on the tariff bill, on May 1, 1828, the Senate voted to table an anti-internal improvements motion stating that the federal government was not responsible for maintaining the Cumberland Road. This motion was put forth by those opposed to the federal role in internal improvements, so the division on this vote is fairly representative of preferences on the issue, as opposed to a vote on a specific funding measure. A vote to table this motion was a vote in favor of federal involvement in internal improvements. The explanatory variables for this vote are the Senator's ideology, government spending in the state on internal improvements over the period 1820 to 1829 (taken from Malone 1998, Appendix A), per capita state wheat production (for Western states who want access to eastern markets), and a dummy variable for states with a coastline (access to the Atlantic Ocean). In results not reported, coastal states were less likely to support internal improvements, but that states that had received large amounts of federal money for internal improvements during the 1820 s were more likely to favor internal improvements, while a legislator's "ideology" score also mattered for the vote. This equation correctly predict 89 percent of those votes with a pseudo $\mathrm{R}^{2}$ of 0.49 .

The predicted vote from this internal improvements vote was used in column (4) of Table 
4. The predicted vote is positive and statistically significant and improves the explanatory power of the regression. The positive value indicates that a favorable vote on internal improvements improves the explanatory power in the tariff vote regression, beyond state-level trade-related characteristics. In addition, the coefficient on wheat production now becomes more precisely estimated (i.e., becomes statistically significant), although its magnitude does not change. Similar results are reported in Minicucci (2004), thus supporting the view that Congressional votes on the tariff and internal improvements were linked.

\section{Breaking the North-West Coalition: Jackson's Maysville Veto}

The success of the North-West coalition in raising tariffs during the 1820s gave the South a powerful incentive to create a wedge between the two regions, or delink the tariff and internal improvements by finding a new political issue on which the North and West opposed each other but where the South could provide some accommodation to the West. ${ }^{7}$ As Senator William Smith of South Carolina astutely observed, "Destroy the tariff and you will leave no means of carrying on internal improvements; destroy internal improvements and you leave no

${ }^{7}$ Federal land policy was potentially one such issue. The West wanted federal land in the new territories to be sold at low prices (a policy called graduation) in order to attract new settlers. The North wanted federal lands to be sold at high prices to limit migration to the West. Revenues from the land sales would simply be returned to the states in lump sums (a policy called distribution) for spending on education or internal improvements. In one scenario, the South could offer graduation to the West, splitting it from the North, in exchange for the West's votes on lower tariffs. But the South was not solidly in favor of low land prices, which would create a greater fiscal need for the tariff, and the West did not want to give up the tariff revenues that would finance internal improvements. Thus, as Feller (1984, pp. 123-124) notes, the South and West "could not combine to enact measures of mutual benefit, for there were none such [issues] ... . Rather, each of two regions with virtually nothing in common would have to act directly against its own interests on one issue in hope of reciprocation on another. An alliance dependent upon such extraordinary trust was naturally liable to collapse at any moment." 
motive for the tariff" (Feller 1984, p. 136).

How did the South finally succeed in breaking the North-West coalition? The defining moment was President Andrew Jackson's veto of the Maysville Road Bill in May 1830. Under the bill, the federal government would have subscribed to stock and helped finance road improvements. There was nothing particularly unusual about the bill, as Congress had enacted similar measures in the past. But Jackson, whose views on internal improvements had been vague up to this point, vetoed the bill. Jackson raised constitutional questions about the measure and noted that the road was wholly within Kentucky and was therefore a local project, not a national one. ${ }^{8}$ Three days later Jackson vetoed another turnpike bill on similar grounds. One motive for the vetoes, Jackson later explained, was to end "flagicious logg-rolling legislation" (Feller 1984, p. 139).

These vetoes completely changed the dynamics in Congress that in the 1820 s had led to higher tariffs and higher spending on improvements. Senator Thomas H. Benton of Missouri wrote that the Maysville veto was "a killing blow" to a national system of internal improvements (Clanin 1982, p. 51). Looking back, Vice President Martin Van Buren called the veto "the entering wedge to the course of action by which that powerful combination known as the Internal Improvement party was broken asunder and finally annihilated" (Feller 1984, p. 141). Historians have agreed: Clanin (1982, p. 53) calls the Maysville veto "a decisive turning point" in ending

8 "The veto message was a hodgepodge of constitutional and expedient arguments, but in its very logical fuzziness lay its political strength. The nebulous distinction between national and local works stung American System men to fury, for it freed Jackson to decide on individual bills precisely as he chose - a freedom he exploited to the utmost." Feller (1984), p. 139. Personal politics also played a role as the bill was a pet project of Henry Clay, who had cost Jackson the presidency in 1824 . 
hopes for systematic federal plans for internal improvements, while Feller (1984, p. 141) believes that it was "not the end, but it was the beginning of the end" of the federal role. The veto did not prevent further federal spending on internal improvements (in fact, such spending surged briefly during the early 1830s), but the spending was worked into general appropriations bills rather than being part of a formal system (Wallis and Weingast 2005, Minicucci 2004).

Jackson's veto changed the political dynamics that tied tariffs and internal improvements together, effectively delinking the two issues and ending hopes for the American System. The impact of the veto can be illustrated in Figure 2, which presents a stylized version of coalition formation in a two dimensional policy-space (Hinich and Munger 1997). The figure presents the ideal combination of tariff and internal improvement policies from the standpoint of each region. The South's “ideal point” combines low tariffs and little spending on internal improvements. The West prefers somewhat higher tariffs but much greater spending on internal improvements. The North favors high tariffs but not as much spending on internal improvements as the West. Each region loses utility the further policies depart from its ideal point, and this is indicated by the indifference curves that move away from the ideal point. (In the case of the South, the indifference curves can be elongated to show strong preference for lower tariffs and a weaker preference for lower spending on internal improvements.) The tangencies of each region's indifference curves yields the set of points that form the Pareto set of policy options, i.e., the set of policies in which no region can be made better off without making another worse off. The equilibrium policy will be somewhere in this set, but its precise location is determined by other factors.

The point 1828 is a policy mix in the Pareto set that combines high tariffs and high 
spending on internal improvements. The point is somewhere between the ideal points of the West and the North, but furthest from the South. Although the location of this point has been determined arbitrarily, it implies that the North and West have formed a coalition against the interests of the South. The tangency of the North and South indifference curves implies that they are adamantly opposed to each other on the issue, with no possible gains from voting trading.

Although bargaining by these sectional economic interests over tariffs can account for the 1828 legislation, the point labeled " 1828 " in Figure 2 is not in itself a stable equilibrium. As suggested earlier, when there are two or more dimensions to a policy choice, any majority coalition is potentially vulnerable to a proposal by a minority to tempt some portion of the majority away (Hinich and Munger 1997, Weingast 1998). Since all policy alternatives have this property, voter preferences alone cannot explain the equilibrium policy outcome or determine whether it remains stable. For example, Figure 3 presents the indifference curves through the policy point labeled 1828. Because the point lies on the line indicating a tangency between the indifference curves of the North and South, there are no possible gains that would allow these regions to cooperate over tariff policy; their interests are diametrically opposed. However, there are two areas of unexploited gains from vote trading: the North and West could each benefit from exchanging votes that entail greater spending on internal improvements with little change in tariffs, and the South and West also share a policy region in which they can benefit from lower tariffs without much change in spending on internal improvements.

To avoid this indeterminacy, or the constant cycling of policy implied by this two dimensional setup, Shepsle and Weingast (1979) introduced the notion of a "structure-induced" equilibrium. Legislative practices and institutions, such as closure rules and committees with 
agenda control or other gate keeping functions, bring stability to policy and prevent cycling. Another equilibrium-inducing institution is the presidential veto (Carter and Schap 1987). The presidential veto can rule out certain policy combinations in the Pareto set and confine policy to certain dimension. For example, the impact of a presidential veto of federal spending on internal improvements can be seen in the context of Figure 3. A veto of any bill proposing higher tariffs would restrict the set of possible Pareto-improving policies to those below the current level of internal improvement spending. The only area that is then available for two parties to trade votes and improve their position is the South and the West, which could agree to reduce the tariff in exchange for modest reductions in internal improvement spending.

This framework illustrates how Jackson's Mayville veto broke the North-West alliance by de-linking tariffs and internal improvements. By effectively ruling out a larger role for the federal government in internal improvements, the veto constrained the direction of future policy changes. ${ }^{9}$ Thus, the veto helps to explain why tariffs stopped rising, but does not explain why they began to fall.

\section{Securing the Great Compromise: Congressional Commitment or Economic Interests?}

Jackson's Maysville veto helped stop the drift toward ever higher tariffs, but what explains the Great Compromise of 1833 that put tariffs on a downward track?

In the aftermath of the Tariff of Abominations of 1828, the South, particularly South

9 The fact that federal spending on internal improvements continued to increase for several years after the veto does not overturn this effect. The veto delinked the tariff and internal improvement issues, but did not prevent smaller internal improvement projects with different coalitions from getting passed by Congress in appropriations bills. 
Carolina, was seething with anger over these high import duties. The Southern denunciation of the tariffs with strong rhetoric about states rights, along with the desire of the Jackson administration to defuse the tensions, forced Congress to revisit the tariff question and accommodate the South. In January 1832, Henry Clay introduced a measure to abolish all tariffs on goods that did not compete with domestic production, a measure that would have reduced tariff revenue but preserve the protective tariff. Various other tariff proposals came before Congress. Although the tide had shifted in favor of those supporting lower tariffs, the factions that previously supported high tariffs did not simply evaporate. The new tariff, enacted in July 1832, eliminated duties on coffee, tea, and wine, but kept rates high on cotton, woollens, and iron.

However, with the issue of federal internal improvements largely put to rest, the West was no longer a decisive factor behind the bill's passage. In fact, as Table 2 shows, even the South was split over the measure in the House. But the "compromise" of 1832 failed to South Carolina and others since the tariff structure that preserved the protective tariffs of the American system even as it eliminated duties on household consumption items.

Having lost hope that tariff reform could ever be achieved at the federal level, the state legislature of South Carolina passed the nullification act in November 1832, declaring that the tariff acts of 1832 and 1828 were unconstitutional and therefore null and void in the state (Freehling 1965). Furthermore, South Carolina threatened to secede from the Union if the federal government attempted to enforce the tariff in the state. In what was arguably the most serious crisis in U.S. history up to that point, South Carolina - by proposing that states could have veto power over Congressional legislation - was challenging the very foundation of the 
federal system. While not going as far as South Carolina, the state legislatures of Alabama, Mississippi, Virginia, and Georgia concurred in viewing protective tariffs as being unconstitutional.

The political stakes were huge. An outraged President Jackson responded by seeking legislation allowing him to compel, by force if necessary, the enforcement of the tariff in South Carolina. At the same time, he sought Congressional action to accommodate the South over the tariff issue. To head off any immediate and radical reductions in tariffs, Henry Clay unveiled his compromise measure in February 1833. The compromise promised to phase out protectionist tariffs (defined as those above 20 percent) and bring all tariffs to a uniform level by 1842 . Manufacturers competing against imports would have nine years to adjust to the lower tariffs, and in time the South would see the 40 to 50 percent tariffs come down to 20 percent. $^{10}$

Clay secured the support of John Calhoun before introducing the compromise plan, and so the bill moved quickly through a Congress that was anxious to defuse the crisis. The House approved the bill on February 25, the Senate passed it on March 1, and President Jackson signed it on March 2. ${ }^{11}$ As the voting tabulation in Table 2 indicates, the South strongly approved the compromise, the West approved it by a clear majority, while the North voted largely against the measure. The defection of the West did not go unnoticed by pro-tariff politicians in the North: as the compromise was being debated, George Briggs of Massachusetts observed that "We are now

10 As Peterson (1982, p. 53) put it, "The formula traded time, which was of first importance to manufacturers, for principle, which was of first importance to the South."

${ }^{11}$ Clay also succeeded in enacting a bill to distribute the revenue from land sales to the states (distribution) so that local funding for internal improvements could continue, but Jackson pocket vetoed the measure. 
soon to know, Mr. Chairman, whether this [protective] system, in which New England is so vitally interested, against her remonstrance, is to be overthrown by a combination of Southern votes with the votes of the Western and Middle States" (January 14, 1833, p. 1040).

The compromise provided that all duties above 20 percent would be reduced by one tenth of the excess above 20 percent starting in January 1834, with another one tenth deducted in January 1836 , another in January 1838 , and another in January 1840 , amounting to a 40 percent reduction in the excess over 20 percent. In 1842, the remaining 60 percent excess over 20 percent would be removed, three tenths of the excess in January 1842 and another three tenths in July 1842. By the end of the transition period, the United States would have a uniform 20 percent tariff on all dutiable imports. ${ }^{12}$ The compromise bill pledged that "until the $30^{\text {th }}$ day of June, 1842, the duties imposed by existing laws, as modified by this act, shall remain and continue to be collected. And from and after the day last aforesaid, all duties upon imports ... shall be laid for the purpose of raising such revenue as may be necessary to an economical administration of the government."

But as with any intertemporal bargain, it was one thing to pass the compromise measure, and yet another to ensure that it was enforced. The South bore much of the risk in the compromise because the low duties it sought would arrive only after a period of nine years. The South rightly feared that Congress could renege at any time on its intention either to reduce duties during the 1833 to 1842 period or to maintain the lower duties after 1842 . The South was

12 Thus, this was a typical back-end loaded tariff reduction in which sixty percent of the reduction takes place in the last year of the phase out. At the end of the transition period, specific duties would not necessarily be set at 20 percent because their ad valorem equivalent would fluctuate with import prices. 
wary of the compromise because, as Representative Thomas Foster of Georgia aptly put it, the current Congress "had no power to bind our successors" (February 26, 1833, p. 1792).

In presenting the compromise, Clay assured the South that it would not be tampered with, arguing that

"the best guaranties would be found in the circumstances under which the measure would be passed. . . . if the measure should be carried by the common consent of both parties, we shall have all security; history will faithfully record the transaction; narrate under what circumstances the bill was passed; that it was a pacifying measure, that it was as oil poured from the vessel of the Union, to restore peace and harmony to the country. When all this was known, what Congress, what Legislature, would mar this guaranty? What man, who is entitled to deserve the character of an American statesman, would stand up in his place, in either House of Congress, and disturb this treaty of peace and amity?" (February 12, 1833, p. 468).

If the bill passed with the consent of all, Clay "had no doubt [that] the rate of duties guarantied would be continued after the expiration of the term, if the country continued at peace."

Alternatively, the North feared that the compromise would handcuff future Congresses and prevent them from protecting industries even if circumstances were to change. To answer these charges, Clay admitted that "the bill contains no obligatory pledges - it could make none, none are attempted ... . The next Congress, and every succeeding Congress, will undoubtedly have the power to repeal the law whenever they may think proper... . The measure is what it professes to be, a compromise; but it imposes, and could impose, no restriction upon the will or power of a future Congress" (February 25, 1833, pp. 730-31).

While Clay agreed that the compromise could not bind the actions of any future Congress, he believed that future Congresses would be bound by the compromise and would fear the consequences of tampering with it. As it turned out, Clay was mostly correct. From 1833 until 1842, as provided under the compromise, the staged tariff reductions took effect without 
any interference from Congress and the average tariff on dutiable imports fell from 60 percent to 30 percent in less than a decade (Figure 1).

Why was the measure not disturbed? Certainly the compromise was often described in solemn terms - as "sacred," "the highest moral obligation," "the great bond of peace to this Union" - but to conclude that it was untouchable is an insufficient explanation. ${ }^{13}$ The proximate reason the Compromise was not touched prior to 1842 was that the Jacksonian Democrats controlled the House of Representatives, the Senate, and the presidency in every year from 1833 until 1841. Since the Democrats were largely responsible for enacting the compromise, the fact that they remained in power meant that Whigs and others who preferred higher tariffs did not have the political opportunity to change the measure. In addition, until the Panic of 1837 , the economy remained strong and the government's fiscal surpluses allowed the continued repayment of government debt.

But the fragility of the Compromise was demonstrated when the Whigs swept into office with the election of 1840. Although the Whigs supported higher tariffs, President John Tyler, who came from the South and took office after William Harrison died shortly after his inauguration in 1841, was much less favorable to them. Despite the economic downturn and the growing fiscal deficit, Tyler stated that "the compromise act should not be altered except under urgent necessities which are not believed at this time to exist." Yet the federal government

13 "For the next nine years the tariff of 1833 enjoyed an almost sacred inviolability as the act that saved the union," writes Feller (1984, p. 169). But Stanwood (1903, II, p. 11) writes: "The act of 1833 was not more sacred or more irrepealable than any other measure passed by the same authority; but the circumstances in which it was passed imposed it as a point of honor upon certain influential statesmen to oppose a change until the expiration of the period at the end of which it was to come into full effect, that is, until the year 1842." 
incurred a \$10 million budget deficit in fiscal year 1841, and was forecast to lose another $\$ 5$ million per year as a result of the steep tariff cuts due to take effect in 1842. By mid-1842, some revenue-raising action was required, and so the Whigs passed bills imposing higher tariff rates (similar to the 1832 legislation). ${ }^{14}$ The House passed the measure by a single vote, with overwhelming support from the North, complete opposition by the South, and a majority against in the West. The West also split in the Senate, signaling that it no longer stood with the North in favor of high tariffs. Tyler reluctantly signed the bill, which helped push up the average tariff on dutiable imports from 26 percent in 1842 to 37 percent in 1844, as Figure 1 shows.

Thus, the low tariffs envisioned by the compromise were in effect for just two months, July and August 1842. Many representatives from the South were outraged. John Calhoun summed up the complaints of many: "We have patiently waited the nine years of slow reduction, and resisted every attempt to make changes against the manufacturing interest, even when they would have operated in our favor, and for which we have received the thanks of those who represented it on this floor. And now, when the time has arrived, when it is our turn to enjoy its benefits, they who called on us to adhere to the act, when the interest of the manufactures was at stake, and commended us for our fidelity to the compromise, turn round, when it suits their interest, and cooly and openly violate every provision in our favor" (March 16, 1842, p. 225). Representative John Jones of Virginia argued that for nine years, "while the South had to bear the burdens of the arrangements, it tamely and quietly submitted to the consequences. . . Now, when

\footnotetext{
14 Congress passed two tariff bills in July and August 1842, but combined them with the distribution of revenues from land sales to states. Tyler vetoed both bills, as he adamantly opposed the distribution of land revenue as violating the spirit of the compromise because tariffs were above 20 percent and the federal government desperately needed funds. Congress finally passed the tariff without the distribution provision.
} 
we are to reap the advantages of the compromise act, what is the spectacle which we see exhibited? The very party who enacted the law have come forward and declared that they will not execute the promises nor discharge the obligations there imposed" (June 15, 1842, p. 635). ${ }^{15}$

However, these higher tariffs proved to be short lived as political power shifted back to the Democrats in the 1844 presidential election. With the economy now expanding and the budget deficit eliminated, the Democrats enacted the Walker tariff of 1846, named for Treasury Secretary Robert Walker whose detailed report on the tariff inspired the legislation. The Walker tariff simplified the tariff code, converting all import duties to ad valorem rates and setting up a classification system of just a few rates of duty. Most of the controversial manufactured goods, such as clothing and iron, were put in the 30 percent duty category. Although discussion of the Compromise of 1833 did not figure prominently in the 1846 congressional debate, the Walker tariff was often referred to as a "revenue" tariff, a code word that it was not a protectionist tariff. As Table 2 indicates, the Senate passed the Walker tariff with the strong support of the South and West, and over strong objections from the North.

Under the Walker tariff, average tariffs on dutiable imports slid below 30 percent. In 1857, tariffs were reduced even further, falling below 20 percent in 1859 and 1860. Although tariffs were not as low as many in the South had wanted them during the nullification crisis (15

15 Dixon Lewis of Alabama called the tariff a "gross violation of the compromise act," a compact which he said "had been faithfully kept by the South. . . . We submitted to it for nine years; the manufacturers enjoyed the protection it gave, as witnessed by the fact that it was the only time they had been quiet since the tariff of $1816 .$. not only to supersede, but to violate the spirit of the compromise act" (July 11, 1842, p. 742). William Smith of Virginia stated that "The compromise act had been observed in good faith by one party, while the other had reaped all the benefits from it; but now that the South was to receive its share of the advantages held out by it, gentlemen were anxious to violate it" (July 2, 1842, p. 713). 
percent uniform duties had been proposed), the South had clearly won the battle for lower tariffs. With the exception of the 1842-46 period, tariffs had fallen almost continuously since the Compromise of 1833. What political and economic factors accounts for the persistence of the low tariff equilibrium, particularly after $1846 ?$

The proximate reason that the low-tariff political equilibrium held during this period was that no party except the Democrats ever had simultaneous control of the three bodies - the House, the Senate, and the presidency - required to enact legislation. As Table 5 indicates, unified control of these branches of government was essential to the passage of any tariff legislation during this period. At various points, other parties favorable to tariffs (the Whigs and later the Republicans) would capture part of the government, but by retaining control of at least one of the three bodies the Democrats retained a veto power and could effectively block any effort to raise tariffs. This may explain the continuity in tariff policy from 1846 until 1860, but begs the question of why low tariff interests represented by the Democrats were so well represented in Congress.

The emergence and strengthening of the West's economic interest in open trade helps account for this outcome. The West had always produced exportable goods, such as wheat and corn, flour, and animal products, but high transportation costs effectively insulated them from world markets prior to the 1840s. With the ongoing reductions in transportation costs, this situation was changing. The expansion of agricultural production further west, and the perception that demand in domestic markets was limited, gave the region the hope that it could someday emerge as the "granary of the world." In his tariff report, Robert Walker (1845, p. 13) explicitly sought to energize the support of the West in favor of lower tariffs. He noted the great 
fertile lands of the West were producing an abundance of agricultural produce for which "the home market, in itself, is wholly inadequate." “The States of Ohio, Indiana, and Illinois, if cultivated to their fullest extent, could of themselves raise more than sufficient food to supply the entire home market," Walker noted. "They must have the foreign market, or a large surplus, accompanied by great depression in price, must be the result." Because high U.S. import tariffs effectively impeded agricultural exports, Walker noted that the West "must be the greatest sufferers by the tariff, in depriving them of the foreign market."

As Table 2 indicates, the West provided decisive support for the passage of the Walker tariff: in both the House and Senate, the bill would not have passed if the West had voted the way it had in the 1820s. Why did the West support the tariff reduction? During the Senate debate, James Morehead of Kentucky raised that very question: "How is it that some of the States which built up this [protective] system by the votes of their Representatives and Senators now desert it? Why have Ohio and other States changed, which used to vote unanimously for the protective policy, now that this great policy embraces an interest of three hundred millions of dollars?" Sidney Breese of Illinois immediately replied: "If the manufacturing interests embrace a capital of four hundred millions, the agricultural interests amount to a thousand millions. Illinois wants a market for her agricultural products; she wants the market of the world. Ten counties of that State could supply all the home market. We want a foreign market for our produce, which is now rotting in our granaries" (July 21, 1846, p. 1124). Farmers in the West now joined with planters in the South in a desire for low tariffs.

Empirical evidence that shifting economic interests were behind the West's changing voting patterns in Congress is presented in Table 6. This table uses the same state economic 
interests to explain the House vote in 1828 and 1846. The first column for each year explains the vote solely by the Poole and Rosenthal (1997) first-dimension "ideology" variable, the second column by the state economic interests, and the third with both. The economic interest variables work well in explaining the 1828 vote. Representatives from states with cotton and tobacco production and shipbuilding tended to vote against the higher tariff, whereas states with wheat, iron, and wool voted in favor. These patterns are roughly evident in 1846 as well, with representatives of import competing interests voting against the tariff reduction, although the cotton, tobacco, and shipbuilding interests are less evidently in favor of legislation. However, wheat and flour interests are now aligned more strikingly in favor of the tariff reduction.

The West's interests in trade intensified with the passage of time. First, with the reduction in transportation costs, due largely to the rapid expansion of railroad networks in the 1850s, Western farmers gained much greater access to distant markets (Fishlow 1965). ${ }^{16}$ The volume of grain shipments arriving in Buffalo from the West provides one indicator: as figure 4 shows, grain shipments were at a very low level prior to the mid-1840s, but grew in great strides during the 1850s. The West's hopes of selling more in foreign markets were fulfilled as wheat and wheat flour exports increased from 6 percent of exports during 1836-40 to 11 percent from 1856-60 (Taylor 1951, p. 451). ${ }^{17}$ The irony is that internal improvements made these shipments

${ }^{16}$ Martin (1935, p. 313) writes, "one may say that by 1852 the people of the Mississippi valley had established their wheat (and related) trade on a sound basis, not only with the East and the South but with Great Britain and the Continent . . . . It seems impossible to overestimate the significance of this development of the West ... . In value and volume, the wheat (and related) trade of the Mississippi valley came to equal and rival the cotton trade of the South."

17 The repeal of the Corn Laws in Britain in 1846 and the Crimean War in 1850s also helped increase demand for U.S. grains. James and Lake (1989) argue that the prospective repeal of the Corn Laws in Great Britain facilitated the Congressional enactment of the Walker tariff. 
possible, not so much the canals of the $1820 \mathrm{~s}$ but the railroads of the $1840 \mathrm{~s}$ and $1850 \mathrm{~s} .{ }^{18}$ Thus, the West's latent economic interest in foreign markets became operational toward the end of the antebellum period.

Second, as its economic interests were becoming more closely tied to exports, the political strength of the West was also increasing. As Table 1 shows, from 1820 to 1850, the West gained seats in the House and the Senate almost entirely at the expense of the North, not the South. The new states that entered the union between the tariff votes in 1828 and 1846 (Arkansas, Florida, Michigan, and Texas) added eight new votes in the Senate, seven of which were in favor of the Walker tariff. In the House, Illinois and Indiana split their votes (4 yea, 4 nay) on the 1828 tariff, but voted 10 in favor and 2 against the tariff of 1846 . The West had more votes, and those votes increasingly supported low tariffs.

As a result, the ability of Northern members of Congress to enact protectionist legislation was seriously compromised by the opposition of the South and West. Together the South and West controlled three quarters of the House and two-thirds of the Senate by 1850 . The old economic interests of the South in low tariffs to promote exports were joined by a new one in the West. Their combined political strength meant that the North had little hope of overturning this

18 As Taylor (1951, p. 167) vividly remarks, "The direct trade between the West and the north Atlantic seaboard expanded so rapidly during the fifties that the railroads, the lakes, and the Erie Canal were all needed to deliver western products to the East. . . The Great Lakes served as a gigantic extension of the Erie Canal, and during the fifties railroads, pushing westward from Chicago and Milwaukee, acted as feeders to the Great Lakes trade so that its volume, swollen by the corn of Iowa and the wheat of Illinois, Wisconsin, and Minnesota, grew from year to year in almost geometric ratio." Slaughter (2001) shows that the reduction in internal transportation costs dramatically reduced the gap in prices of wheat and flour between the West and the East: the price of flour in Philadelphia fell from about 60 percent above the price in Cincinnati in the late 1820 s to just 10 percent above the price by 1860 . 
coalition.

\section{Conclusion}

This paper has analyzed one of the two instances in U.S. history when import tariffs were steadily and consistently reduced over time. The explanation for the secular tariff decline between 1833 and 1860 is the shifting political coalitions between the various regions of the country. Through the antebellum period, the North tended to favor high tariffs and the South strongly favored low tariffs, while the West was a pivotal player in tariff politics. Over the course of the 1820s, a coalition in Congress between the North and West linked the issues of tariffs and internal improvements and succeeded in raising average tariffs. This coalition fell apart in 1830 when President Andrew Jackson effectively delinked the two issues by vetoing internal improvement bills and the Compromise of 1833 put tariffs on a downward path for nine years.

However, the Great Compromise of 1833 was not a credible commitment to a lower tariff regime. But as events unfolded, it proved to be a secure political equilibrium. Lower transportation costs as a result of railroads gave the West a growing stake in export markets and hence an economic interest in low tariffs. The economic interests of both the South and the West favored low tariffs, and together they controlled a clear majority of the seats in Congress. As a result, average tariffs exhibited a secular decline from 1833 until 1860. In the absence of the Civil War, these low tariffs might have persisted for some time. 


\section{References}

Bailey, Michael, Judith Goldstein, and Barry Weingast. "The Institutional Roots of American Trade Policy." World Politics 49 (April 1997): 309-338.

Carter, John R., and David Schap. "Executive Veto, Legislative Override, and Structure-Induced Equilibrium." Public Choice 52 (1987): 227-244.

Clanin, Douglas E. "Internal Improvements in National Politics, 1816-1830." In Transportation and the Early Nation. Indianapolis: Indiana Historical Society, 1982.

Feller, Daniel. The Public Lands in Jacksonian Politics. Madison: University of Wisconsin Press, 1984.

Fishlow, Albert. American Railroads and the Transformation of the Antebellum Economy. Cambridge: Harvard University Press, 1965.

Freehling, William W. Prelude to Civil War: The Nullification Controversy in South Carolina, 1816-1836. New York: Harper, 1965.

Hinich, Melvin J., and Michael C. Munger. Analytical Politics. New York: Cambridge University Press, 1997.

Irwin, Douglas A., and Randall S. Kroszner. "Interests, Institutions, and Ideology in Securing Policy Change: The Republican Conversion to Trade Liberalization after Smoot-Hawley." Journal of Law and Economics 42 (October 1999): 643-673.

Irwin, Douglas A. "New Estimates of the Average Tariff of the United States, 1790-1820." Journal of Economic History 63 (June 2003): 506-513.

James, Scott C., and David A. Lake. "The Second Face of Hegemony: Britain's Repeal of the Corn Laws and the American Walker Tariff of 1846." International Organization 43 (Winter 1989): 1-29.

Larson, John L. Internal Improvement: National Public Works and the Promise of Popular Government in the Early United States. Chapel Hill: University of North Carolina Press, 2001.

Malone, Laurence J. Opening the West: Federal Internal Improvements Before 1860. Westport, CT: Greenwood Press, 1998.

Martin, Thomas P. "Cotton and Wheat in Anglo-American Trade and Politics, 1846-1852." Journal of Southern History 1 (August 1935): 293-319. 
Minicucci, Stephen. "Internal Improvements and the Union, 1790-1860." Studies in American Political Development 18 (Fall 2004): 160-185.

North, Douglass C. The Economic Growth of the United States, 1790-1860. New York:

Prentice Hall, 1961.

Peterson, Merrill D. The Olive Branch and the Sword: The Compromise of 1833. Baton Rouge: Louisiana State University Press, 1982.

Pincus, Jonathan J. Pressure Groups and Politics in Antebellum Tariffs. New York: Columbia University Press, 1977.

Poole, Keith, and Howard Rosenthal. Congress: A Political-Economy History of Roll Call Voting. New York: Cambridge University Press, 1997.

Sellers, Charles. The Market Revolution: Jacksonian America, 1815-1846. New York: Oxford University Press, 1991.

Shepsle, Kenneth, and Barry Weingast. "Structure-Induced Equilibrium and Legislative Choice." Public Choice 37 (1981): 503-519.

Slaughter, Matthew. "Does Trade Liberalization Converge Factor Prices? Evidence from the Antebellum Transportation Revolution." Journal of International Trade and Economic Development 10 (September 2001): 339-362.

Stanwood, Edward. American Tariff Controversies in the Nineteenth Century. Boston: Houghton, Mifflin, 1903.

Stratmann, Thomas. "The Effects of Logrolling on Congressional Voting." American Economic Review 82 (December 1992): 1162-76.

Taylor, George R. The Transportation Revolution 1815-1860. New York: Reinhart \& Co., 1951.

U.S. Bureau of the Census. Historical Statistics of the United States, From Colonial Times to 1970. Washington, D.C.: GPO, 1975.

Walker, Robert J. "Report of the Secretary of Treasury on the State of Finances." $29^{\text {th }}$ Congress, $1^{\text {st }}$ Session, December 3, 1845.

Wallis, John, and Barry R. Weingast. "Equilibrium Impotence: Why the States and Not the American National Government Financed Infrastructure Investment in the Antebellum Era." NBER Working Paper No. 11397, June 2005. 
Weingast, Barry R. "Political Stability and the Civil War: Institutions, Commitment, and American Democracy." In Analytic Narratives, edited by Robert Bates et al. Princeton: Princeton University Press, 1998. 
$-33-$

Table 1: Regional Political Representation in Congress, 1820 \& 1850

Percentage Share of Seats

\begin{tabular}{|c|c|c|}
\hline & 1820 & 1850 \\
\hline \multicolumn{3}{|c|}{ House of Representatives } \\
\hline North & 54 & 41 \\
\hline South & 37 & 32 \\
\hline West & 9 & 27 \\
\hline \multicolumn{3}{|l|}{ Senate } \\
\hline North & 48 & 35 \\
\hline South & 39 & 39 \\
\hline West & 13 & 26 \\
\hline
\end{tabular}

Source: U.S. Bureau of the Census (1975), series Y 220-271.

Note: North includes Maine, New Hampshire, Vermont, Massachusetts, Rhode Island, Connecticut, New York, Pennsylvania, New Jersey, Delaware, and Maryland. South includes Virginia, North Carolina, South Carolina, Georgia, Florida, Arkansas, Mississippi, Louisiana, Texas. West includes Ohio, Michigan, Illinois, Indiana, Missouri, Tennessee, Kentucky, Wisconsin, and California (in 1857). 
Table 2: Regional Patterns of Support for Tariff Legislation

Number of Votes, For and Against

A. House of Representatives

\begin{tabular}{|c|c|c|c|c|c|c|c|}
\hline & 1824 & 1828 & 1832 & 1833 & 1842 & 1846 & 1857 \\
\hline Change in Tariff & Higher & Higher & & & Higher & Lower & Lower \\
\hline Date of Vote & April 16, 1824 & April 22, 1828 & June 28,1832 & $\begin{array}{c}\text { February } 26, \\
1833\end{array}$ & August 22, 1842 & July 3,1846 & March 2, 1857 \\
\hline North & $76-37$ & $73-34$ & $79-35$ & $34-75$ & $80-19$ & $27-66$ & $46-35$ \\
\hline South & $1-54$ & $3-50$ & $27-27$ & $55-1$ & $4-50$ & $49-7$ & $45-0$ \\
\hline West & $30-11$ & $29-10$ & $36-3$ & $30-9$ & $20-34$ & $38-22$ & $31-37$ \\
\hline $\begin{array}{l}\text { Vote Excluding } \\
\text { West }\end{array}$ & $77-91$ & $76-84$ & $106-32$ & $89-76$ & $84-79$ & $76-73$ & $77-35$ \\
\hline Vote Total & $107-102$ & $105-94$ & $132-65$ & $119-85$ & $104-103$ & $114-95$ & $122-72$ \\
\hline
\end{tabular}


B. Senate

\begin{tabular}{|c|c|c|c|c|c|c|c|}
\hline & 1824 & 1828 & 1832 & 1833 & 1842 & 1846 & 1857 \\
\hline Change in Tariff & Higher & Higher & Same & Lower & Higher & Lower & Lower \\
\hline Date of Vote & May 13,1824 & May 13,1828 & July 9, 1932 & March 1, 1833 & $\begin{array}{c}\text { August 27, } \\
1842\end{array}$ & July 28, 1846 & $\begin{array}{c}\text { February } 26 \\
1857\end{array}$ \\
\hline North & $14-7$ & $14-7$ & $22-0$ & $11-11$ & $14-4$ & $4-18$ & $8-6$ \\
\hline South & $2-14$ & $1-13$ & $2-12$ & $12-0$ & $2-14$ & $10-5$ & $18-0$ \\
\hline West & $9-0$ & $11-1$ & $8-4$ & $6-5$ & $8-5$ & $14-4$ & $7-6$ \\
\hline $\begin{array}{l}\text { Vote Subtotal (Excluding } \\
\text { West) }\end{array}$ & $16-21$ & $15-20$ & $24-12$ & $23-11$ & $16-18$ & $14-23$ & $26-6$ \\
\hline Vote Total & $25-21$ & $26-21$ & $32-16$ & $29-16$ & $24-23$ & $28-27$ & $33-12$ \\
\hline
\end{tabular}

Source: Voteview. 
Table 3: Geographic Distribution of Federal Spending on Internal Improvements, 18201829

\begin{tabular}{lcc}
\hline \hline & Percentage of Spending & $\begin{array}{c}\text { Percentage of Population } \\
(1830)\end{array}$ \\
\hline North & 49.4 & 47.5 \\
South & 19.0 & 39.9 \\
West & 31.6 & 12.6 \\
\hline \hline
\end{tabular}

Source: Malone (1998), Appendix A, and U.S. Bureau of the Census (1975) series A 195. 
Table 4: Determinants of Senate Voting

Dependent Variable: Final Vote on Passage of the 1828 Tariff Bill

\begin{tabular}{|c|c|c|c|c|}
\hline & $(1)$ & $(2)$ & (3) & (4) \\
\hline \multicolumn{5}{|l|}{ Political Variables } \\
\hline Ideology & $\begin{array}{l}0.63^{*} \\
(0.22)\end{array}$ & -- & $\begin{array}{c}-0.66^{*} \\
(0.36)\end{array}$ & $\begin{array}{l}-3.31 * \\
(1.20)\end{array}$ \\
\hline \multicolumn{5}{|l|}{ Export-Related Activities } \\
\hline Cotton Production & -- & $\begin{array}{l}-0.011 * \\
(0.005)\end{array}$ & $\begin{array}{l}-0.014 * \\
(0.004)\end{array}$ & $\begin{array}{r}-0.012 * \\
(0.007)\end{array}$ \\
\hline Tobacco Production & -- & $\begin{array}{l}-0.032 * \\
(0.019)\end{array}$ & $\begin{array}{l}-0.044 * \\
(0.027)\end{array}$ & $\begin{array}{c}-0.057 * \\
(0.014)\end{array}$ \\
\hline Ship Production & -- & $\begin{array}{l}-0.192 \\
(0.132)\end{array}$ & $\begin{array}{l}-0.093 \\
(0.129)\end{array}$ & $\begin{array}{l}-0.142 \\
(0.127)\end{array}$ \\
\hline Wheat Production & -- & $\begin{array}{c}0.114 \\
(0.124)\end{array}$ & $\begin{array}{c}0.196 \\
(0.159)\end{array}$ & $\begin{array}{l}0.164 * \\
(0.087)\end{array}$ \\
\hline \multicolumn{5}{|l|}{ Import-Competing Activities } \\
\hline Wool Manufactures & & $\begin{array}{l}-0.024 \\
(0.059)\end{array}$ & $\begin{array}{c}0.022 \\
(0.062)\end{array}$ & $\begin{array}{c}0.025 \\
(0.055)\end{array}$ \\
\hline Sugar Production & -- & $\begin{array}{l}0.014 * \\
(0.005)\end{array}$ & $\begin{array}{l}0.020 * \\
(0.006)\end{array}$ & $\begin{array}{l}0.018 * \\
(0.009)\end{array}$ \\
\hline Iron Manufactures & -- & $\begin{array}{l}31.85 * \\
(22.09)\end{array}$ & $\begin{array}{l}44.34 * \\
(28.65)\end{array}$ & $\begin{array}{l}53.22 * \\
(18.15)\end{array}$ \\
\hline Hemp Manufactures & -- & $\begin{array}{l}36.09 * \\
(23.49)\end{array}$ & $\begin{array}{l}46.76^{*} \\
(29.76)\end{array}$ & $\begin{array}{l}90.69 * \\
(39.72)\end{array}$ \\
\hline \multicolumn{5}{|l|}{ Logrolling Indicator } \\
\hline $\begin{array}{r}\text { Predicted Vote on Internal } \\
\text { Improvements }\end{array}$ & -- & -- & -- & $\begin{array}{l}2.74 * \\
(1.09)\end{array}$ \\
\hline Pseudo $\mathrm{R}^{2}$ & 0.14 & 0.59 & 0.60 & 0.66 \\
\hline Percent Correctly Predicted & $68 \%$ & $87 \%$ & $91 \%$ & $91 \%$ \\
\hline
\end{tabular}

Note: Standard errors are robust and have been corrected for clustering on state. Number of Observations $=47$. $*$ indicates significance at the 10 percent level. 
$-38-$

Table 5: Partisan Control of Federal Government, 1831 - 1961

\begin{tabular}{|c|c|c|c|c|}
\hline Session & House & Senate & President & Tariff Passed \\
\hline $1831-1833$ & $\mathrm{D}$ & $\mathrm{D}$ & $\mathrm{D}$ & $\checkmark$ \\
\hline $1833-1835$ & $\mathrm{D}$ & $\mathrm{D}$ & $\mathrm{D}$ & \\
\hline $1835-1837$ & $\mathrm{D}$ & $\mathrm{D}$ & $\mathrm{D}$ & \\
\hline 1837-1839 & $\mathrm{D}$ & $\mathrm{D}$ & $\mathrm{D}$ & \\
\hline 1839-1841 & $\mathrm{D}$ & $\mathrm{D}$ & $\mathrm{D}$ & \\
\hline $1841-1843$ & W & $\mathrm{W}$ & $\mathrm{W}$ & $\checkmark$ \\
\hline $1843-1845$ & $\mathrm{D}$ & $\mathrm{W}$ & $\mathrm{W}$ & \\
\hline $1845-1847$ & $\mathrm{D}$ & $\mathrm{D}$ & $\mathrm{D}$ & $\checkmark$ \\
\hline 1847-1849 & W & $\mathrm{D}$ & $\mathrm{D}$ & \\
\hline 1849-1851 & $\mathrm{D}$ & $\mathrm{D}$ & $\mathrm{W}$ & \\
\hline $1851-1853$ & $\mathrm{D}$ & $\mathrm{D}$ & $\mathrm{W}$ & \\
\hline $1853-1855$ & $\mathrm{D}$ & $\mathrm{D}$ & $\mathrm{D}$ & \\
\hline $1855-1857$ & $\mathrm{R}$ & $\mathrm{D}$ & $\mathrm{D}$ & \\
\hline 1857-1859 & $\mathrm{D}$ & $\mathrm{D}$ & $\mathrm{D}$ & $\sqrt{ }$ \\
\hline 1859-1861 & $\mathrm{R}$ & $\mathrm{D}$ & $\mathrm{D}$ & \\
\hline $1861-1863$ & $\mathrm{R}$ & $\mathrm{R}$ & $\mathrm{R}$ & $\checkmark$ \\
\hline
\end{tabular}

Note: $\mathrm{D}=$ Democrats, $\mathrm{W}=$ Whigs, $\mathrm{R}=$ Republicans.

Source: U.S. Bureau of the Census (1975), series Y 204-210. 
$-39-$

Table 6: Marginal Effects from Probit Regression of House of Representative Votes on Tariff Bills, 1828 \& 1846

\begin{tabular}{|c|c|c|c|c|c|c|}
\hline & & 1828 & & & 1846 & \\
\hline Ideology & $\begin{array}{l}0.77 * \\
(0.25)\end{array}$ & -- & $\begin{array}{l}0.96^{*} \\
(0.28)\end{array}$ & $\begin{array}{c}-3.13^{*} \\
.061\end{array}$ & -- & $\begin{array}{l}-4.78 * \\
(0.79)\end{array}$ \\
\hline $\begin{array}{l}\text { Cotton \& Tobacco } \\
\text { Production }\end{array}$ & -- & $\begin{array}{l}-0.15^{*} \\
(0.002)\end{array}$ & $\begin{array}{l}-0.01 * \\
(0.003)\end{array}$ & -- & $\begin{array}{c}0.00 \\
(0.00)\end{array}$ & $\begin{array}{c}0.00 \\
(0.00)\end{array}$ \\
\hline Ship & -- & $\begin{array}{l}-0.21 * \\
(0.108)\end{array}$ & $\begin{array}{l}-0.23^{*} \\
(0.105)\end{array}$ & -- & $\begin{array}{c}-0.08 * \\
(0.04)\end{array}$ & $\begin{array}{c}.0 .09 \\
(0.08)\end{array}$ \\
\hline Flour & -- & $\begin{array}{l}-0.38 \\
(0.04)\end{array}$ & $\begin{array}{c}0.23 \\
(0.036)\end{array}$ & -- & $\begin{array}{l}0.14 * \\
(0.06)\end{array}$ & $\begin{array}{l}0.16^{*} \\
(0.09)\end{array}$ \\
\hline Wheat & -- & $\begin{array}{c}0.018 \\
(0.013)\end{array}$ & $\begin{array}{l}0.025^{*} \\
(0.011)\end{array}$ & -- & $\begin{array}{l}-0.01 \\
(0.02)\end{array}$ & $\begin{array}{l}0.014 * \\
(0.006)\end{array}$ \\
\hline $\begin{array}{l}\text { Iron Manufactures } \\
\text { (capital invested) }\end{array}$ & -- & $\begin{array}{c}0.180 * \\
(0.09)\end{array}$ & $\begin{array}{l}0.22 * \\
(0.08)\end{array}$ & -- & $\begin{array}{l}-0.17 * \\
(0.06)\end{array}$ & $\begin{array}{l}-0.372^{*} \\
(0.069)\end{array}$ \\
\hline $\begin{array}{l}\text { Cotton Manufactures } \\
\text { (capital invested) }\end{array}$ & -- & $\begin{array}{c}-0.00 \\
(0.007)\end{array}$ & $\begin{array}{l}-0.01 \\
(0.01)\end{array}$ & -- & $\begin{array}{l}0.06^{*} \\
(0.02)\end{array}$ & $\begin{array}{l}-0.023 \\
(0.022)\end{array}$ \\
\hline $\begin{array}{l}\text { Wool Manufactures } \\
\text { (capital invested) }\end{array}$ & -- & $\begin{array}{l}-0.004 \\
(0.040)\end{array}$ & $\begin{array}{c}0.004 \\
(0.036)\end{array}$ & -- & $\begin{array}{l}-0.79 * \\
(0.17)\end{array}$ & $\begin{array}{l}0.347 * \\
(0.188)\end{array}$ \\
\hline Wool & -- & $\begin{array}{c}0.17 * \\
(0.107)\end{array}$ & $\begin{array}{l}0.24 * \\
(0.10)\end{array}$ & -- & $\begin{array}{c}0.12 \\
(0.10)\end{array}$ & $\begin{array}{l}-0.295^{*} \\
(0.139)\end{array}$ \\
\hline Sugar & -- & $\begin{array}{c}0.016 * \\
(0.004)\end{array}$ & $\begin{array}{l}0.01 * \\
(0.00)\end{array}$ & -- & $\begin{array}{c}-0.01 * \\
(0.00)\end{array}$ & $\begin{array}{c}-0.001 \\
(0.002)\end{array}$ \\
\hline Percent Correctly Predicted & $72 \%$ & $79 \%$ & $86 \%$ & $92 \%$ & $75 \%$ & $96 \%$ \\
\hline Pseudo $\mathrm{R}^{2}$ & 0.18 & 0.53 & 0.61 & 0.74 & 0.35 & 0.88 \\
\hline
\end{tabular}

Standard errors are robust and have been corrected for clustering by state. * indicates significant at 10 percent level. Constant term not reported. Independent variables have been standardized to facilitate comparison. Production data taken from the 1840 Census. Number of observations: 199 for 1828,209 for 1846. 
$-40-$

Figure 1: Average U.S. Tariff on Dutiable Imports, 1816-1860

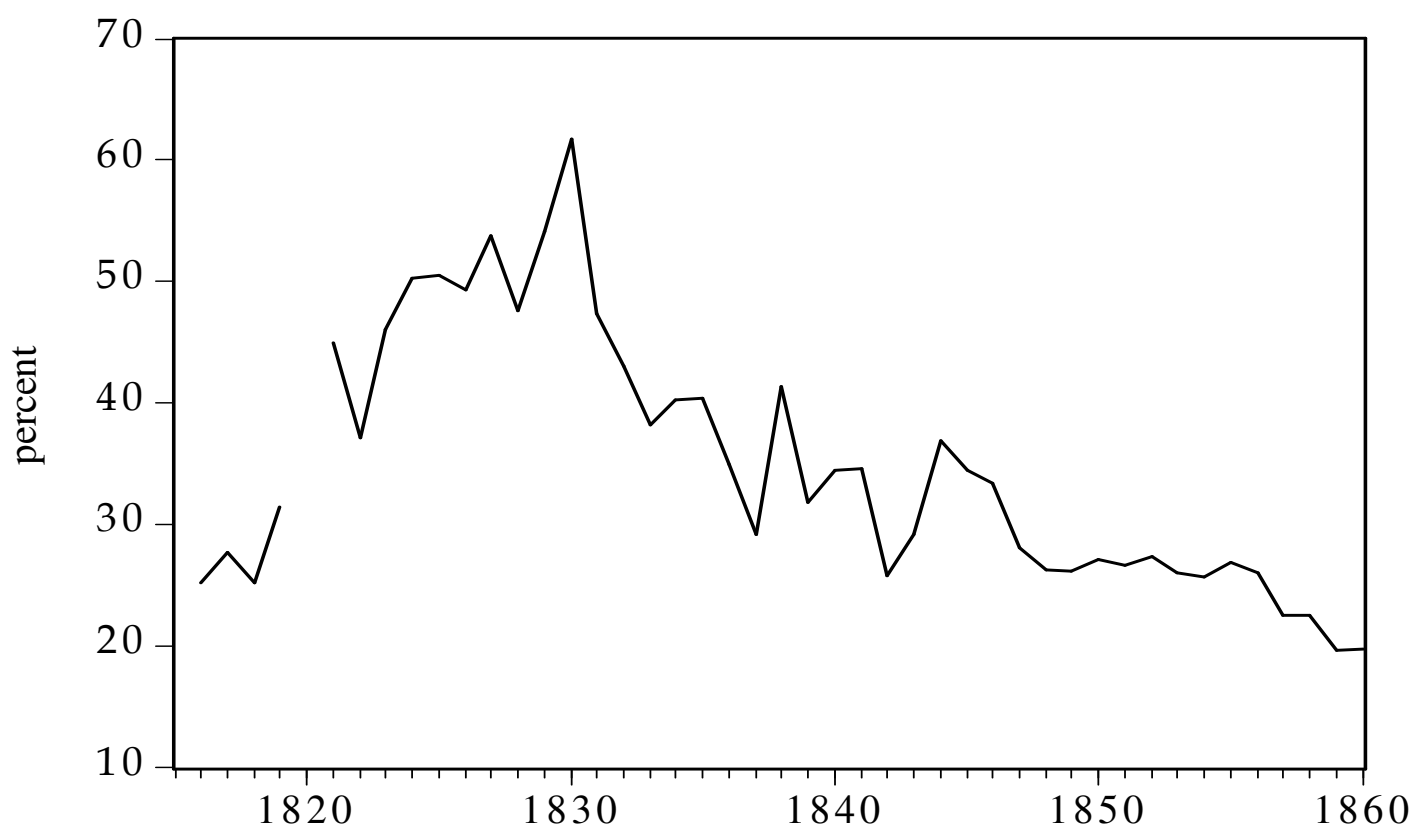

Note: No data are available for 1820.

Source: For 1816 - 1820, Irwin (2003), Table 1. For 1821-1860, U.S Bureau of Census (1975), series U 212. 
Figure 2: Regional Preferences over Tariffs and Internal Improvements

Internal Improvements

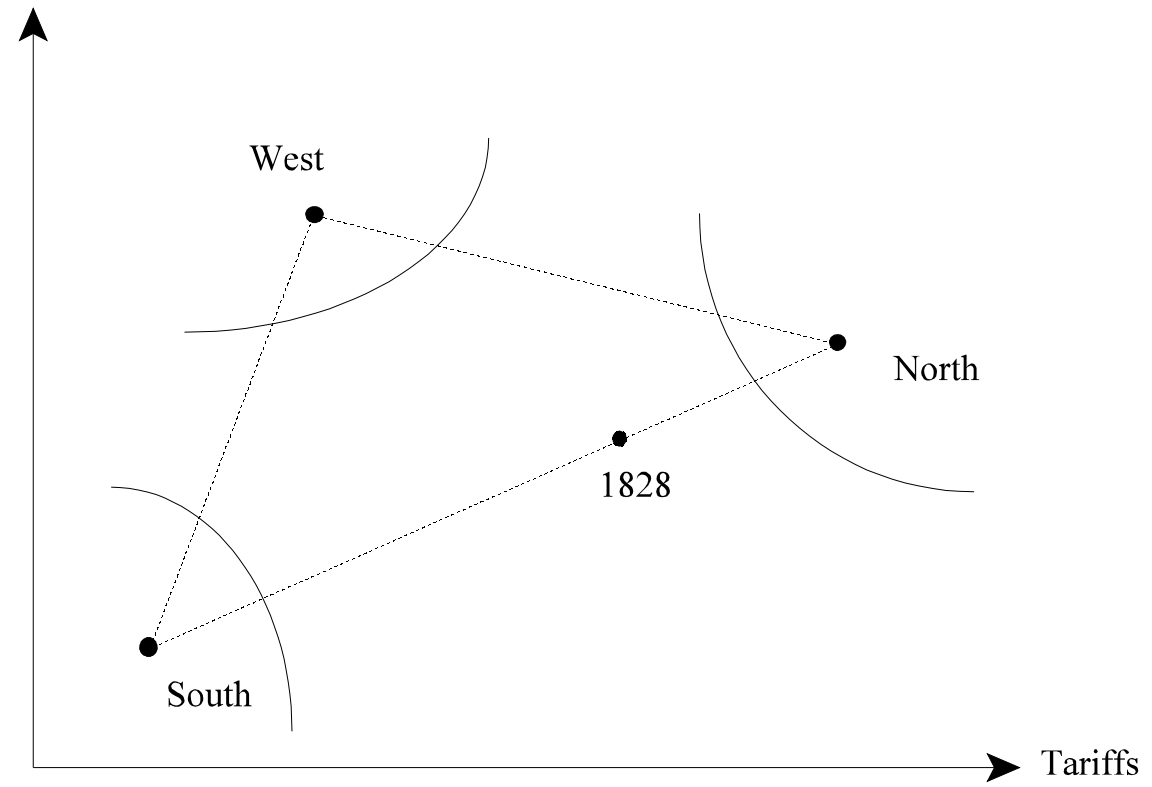


Figure 3: Impact of Presidential Veto on Feasible Coalitions over Tariffs and Internal Improvements

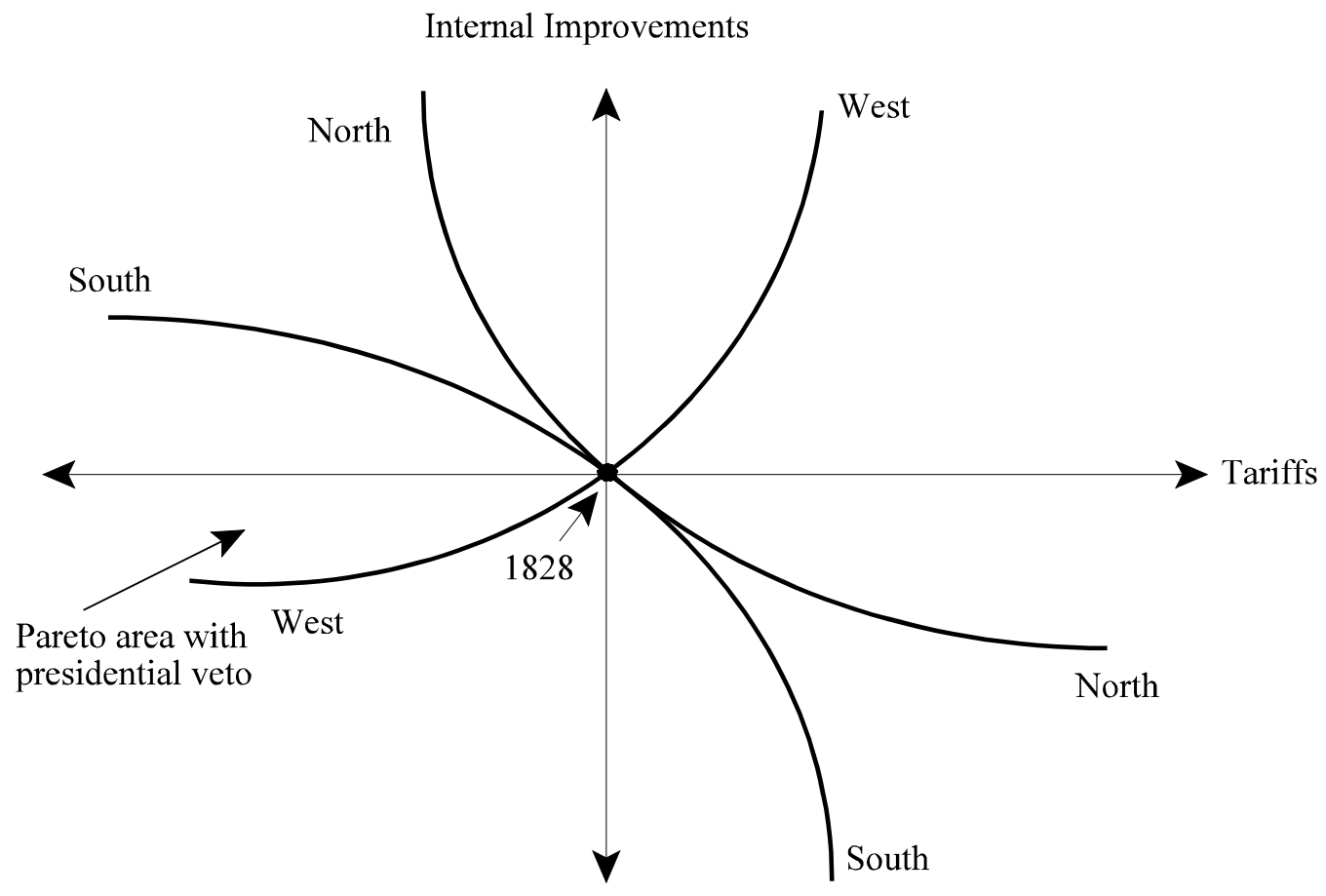


Figure 4: Grain Shipments Received at Buffalo from the West, 1836 - 1860

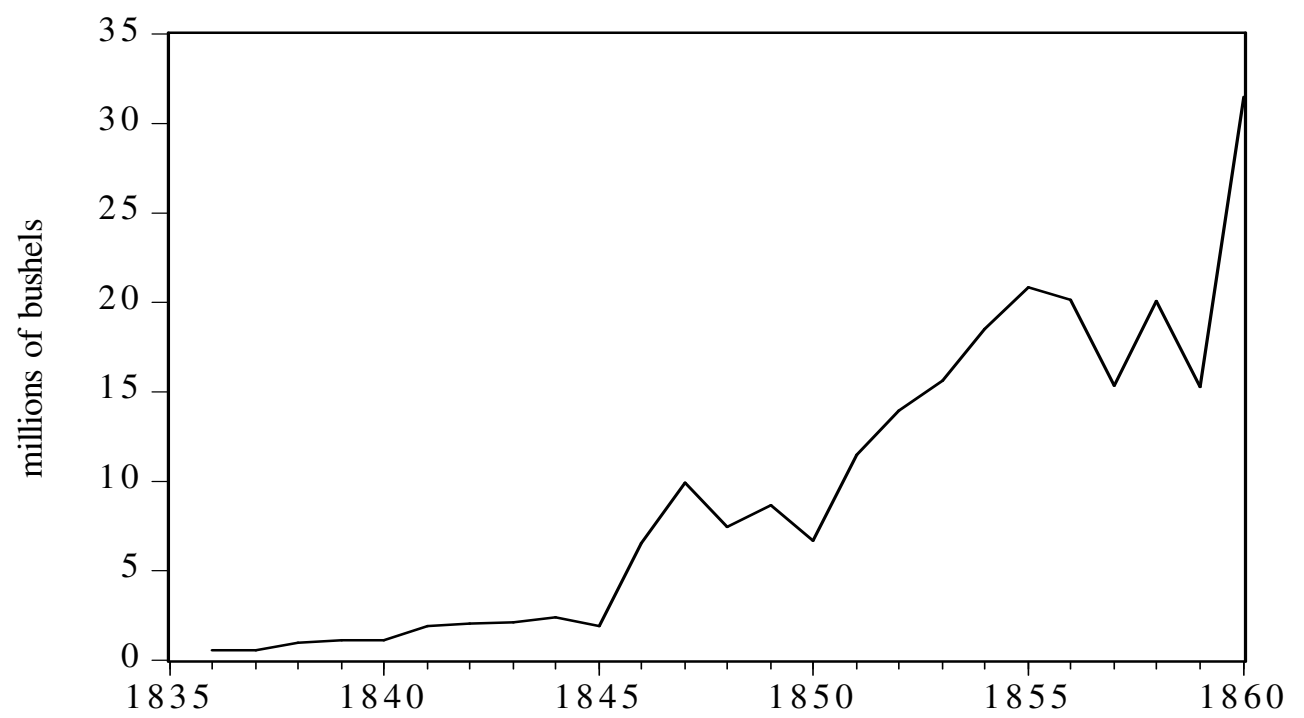

Source: North (1961), p. 253. 